\title{
The trace fossil Yakutatia emersoni from the Matapedia Basin of New Brunswick and southeast Gaspé - its first reported occurrence outside of Alaska
}

\author{
R.K. Pickerill, Department of Geology, \\ University of New Brunswick, Fredericton, N.B. E3B 5A3
}

\begin{abstract}
The trace fossil Yakutatia emersoni is recorded and described from the Late Ordovician-Early Silurian Matapedia and Grog Brook groups of northwest New Brunswick and southwest Gaspé. The recording has three important consequences. First, it represents the first report of the trace fossil outside its type locality on Kodiak Island, Alaska. Second, it extends the stratigraphic range of the ichnospecies, previously known only from the Cretaceous, back to the Late Ordovician, probably Gamachian. Third, it confirms the preferred environment in which the producing organism inhabited as deep water marine.

On rapporte et décrit la trace fossile Yakutatia emersoni dans les groupes de Matapedia et de Grog de l'Ordovicien tardif au Silurien precoce du nord-ouest du Nouveau Brunswick et du sud-ouest de Gaspé. Trois conséquences importante découlent de ce rapport: 1. On rapporte cette trace fossile pour la première fois hors de sa localite-type sur l'île de Kodiak, en Alaska; 2. Bien que cette ichnoespèce ne soit connue qu'au (rétacé, on recule son étendue stratigraphique jusqu'à l'Ordovicien tardif (probablement jusqu'au Gamachien; 3. On confirme que l'organisme qui produisait cette trace préférait un environnement d'eau profonde.
\end{abstract}

[Traduit par le journal]

\section{INTRODUCTION}

Yakutatia is an enigmatic but distinctive spiralled graphoglyptid (Seilacher 1977) trace fossil ichnogenus currently represented by a single ichnospecies, Yakutatia emersoni, which was originally collected and described by Ulrich (1904) from the Cretaceous Kodiak Formation of Kodiak Island, Alaska. Ulrich (1904) originally referred to the trace fossil as Gyrodendron emersoni, but at a later date Hantzschel (1962) changed the name to Yakutatia emersoni as Gyrodendron, unbeknownst to Ulrich, had previously been utilized by Quenstedt (1880) for a scleractinian coral (Wells 1956). Until recently the nature of Yakutatia and its detailed occurrence was poorly known. McCann and Pickerill (1986), however, recently re-examined type, topotype and other material from Kodiak Island, and, in addition to providing a more complete morphological description of the trace fossil, concluded that, at least in Alaska, it was associated with a lobe fringe environment of a large submarine fan. They also noted that the trace fossil had never been described from outside of its type location.

The purpose of this short paper is, therefore, to report the first occurrence of Yakutatia emersoni outside of Alaska. The recording is also important because,

MARITIME SEDIMENTS AND ATLANTIC GEOLOGY 2l, 47-54 (1985) first, it extends the stratigraphic range of the trace fossil to the Late Ordovician, probably Gamachian, and second, it confirms the preferred (and only known) environment in which the producing organism inhabited as deep water marine.

\section{LOCATION AND STRATIGRAPHY}

Specimens described herein form part of an extensive and diverse collection of trace fossils made over the previous several years from northwest New Brunswick and southeast Gaspé. Although preliminary reports on these collections have been previously made by Pickerill (1980, 1986) and Pickerill and Forbes (1980), no detailed and systematic studies have yet been undertaken, though this particular aspect is currently in preparation. All the collections are from the Aroostock-Matapedia Carbonate Belt of Ayrton et al. (1969), also known as the Aroostook Anticlinorium (Rodgers 1970), the AroostookMatapedia Trough (Bradley 1983) and herein, following Fyffe et al. (1981), referred to as the Matapedia Basin. This basin comprises a narrow tectonostratigraphic zone extending from eastern Gaspé through New Brunswick and into northern Maine (Fig. l), where it merges with the Merrimack Trough (Bradley 1983) The Ordovician and Silurian stráta comprising this basin have been assigned various group or formational names at different locations along its length. In northwest New Brunswick all specimens 


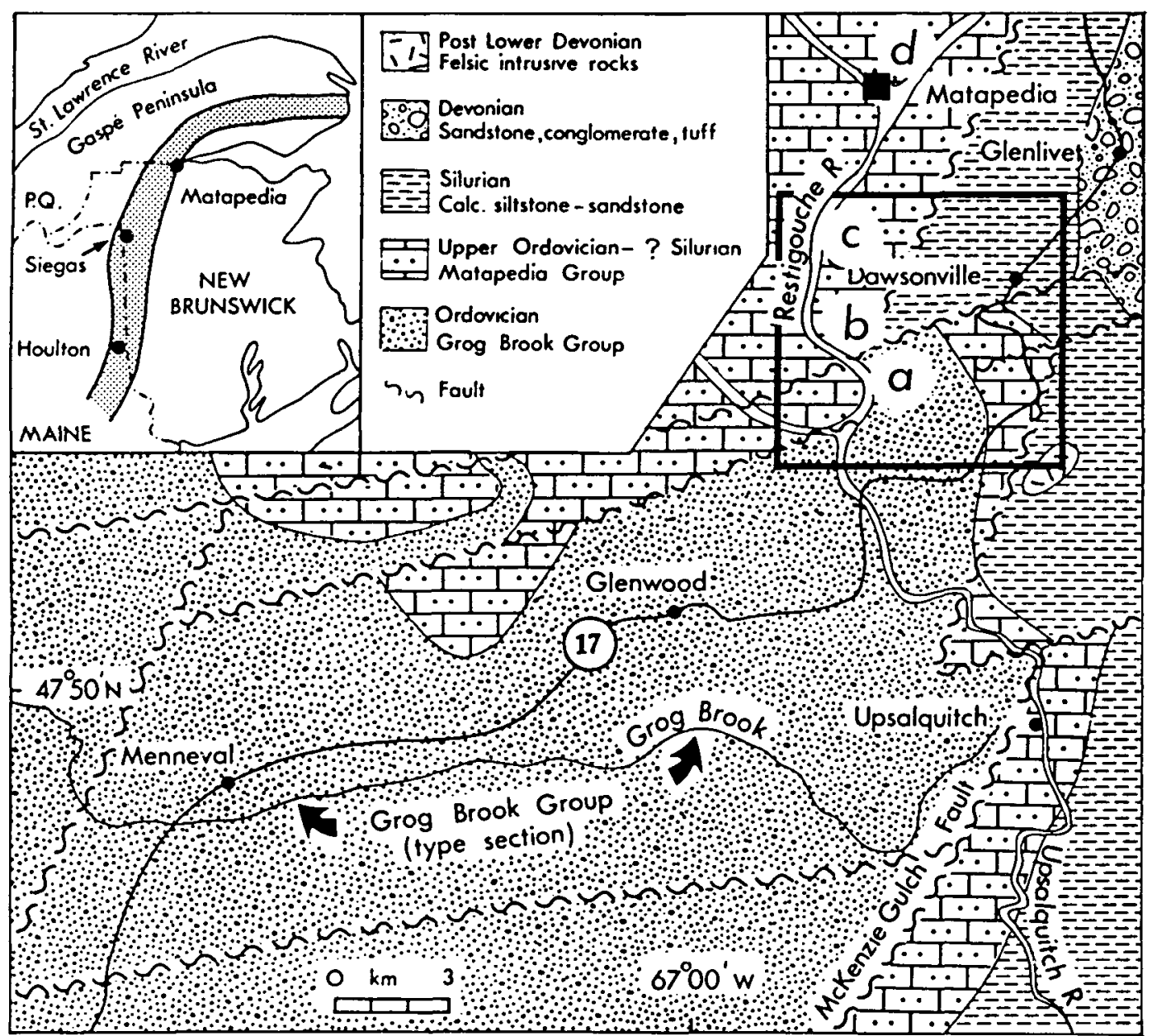

Fig. 1 - Generalized geological map of the Matapedia Basin in northwest New Brunswick (modified after St. Peter 1977; Nowlan 1983) illustrating locations a-d inclusive where Yakutatia, as described herein, was collected. Boxed area containing locations a-c inclusive is illustrated in Figure 2 . Inset map indicates general distribution of Matapedia Basin in Gaspe, New Brunswick and Maine.

were collected from the oldest exposed strata within the basin, the Grog Brook and Matapedia groups, and which are Late Ordovician-Early Silurian in age. In southwest Gaspé specimens were collected from the coeval Matapedia Group.

Although partially complete and fragmentary specimens of Yakutatia emersoni have been observed at several additional locations, those described herein were more complete and were made at four locations (Figs. 1,2). These are:

1. The Grog Brook Group on the eastern (New Brunswick) bank of the Restigouche River at Runnymede, $400 \mathrm{~m}$ south of the confluence with Rafting Ground Brook (a in Figs. 1,2; NTS 21-0/15, lat. $47^{\circ} 54^{\prime} 30^{\prime \prime}$ $\mathrm{N}$, long. $\left.66^{\circ} 56^{\prime} 57^{\prime \prime} \mathrm{W}\right)$.

2. The Matapedia Group on the eastern
(New Brunswick) bank of the Restigouche River at Runnymede, $300 \mathrm{~m}$ north of the confluence with Rafting Ground Brook

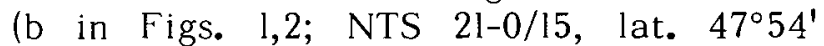
$40^{\prime \prime} \mathrm{N}$, long. $\left.66^{\circ} 57^{\prime} 45^{\prime \prime} \mathrm{W}\right)$.

3. The Matapedia Group on the eastern (New Brunswick) bank of the Restigouche River, $100 \mathrm{~m}$ north of the confluence with Dawson Brook (c in Figs. 1,2; NTS 21-0/15 lat. $47^{\circ} 55^{\prime} 35^{\prime \prime} \mathrm{N}$, long $\left.66^{\circ} 56^{\prime} 55^{\prime \prime} \mathrm{W}\right)$.

4. The Matapedia Group on the highway section (\#132) at Matapedia, Quebec (d in Fig. l; NTS 21-0/15, lat. $47^{\circ} 58^{\prime} 40^{\prime \prime} \mathrm{N}$, long. $\left.66^{\circ} 56^{\prime} 55^{\prime \prime} \mathrm{W}\right)$.

Conodonts recovered by Nowlan (1983) from location a have yielded a Late Ordovician, probably Gamachian age. The graptolite Dicellograptus cf. complanatus recorded by Rickards and Riva (1981) from location b also indicates a Late Ordo- 
vician age. Because of the absence of faunas, the precise age of locations $c$ and $\mathrm{d}$ is unknown and could conceivably extend into the Early Silurian.

\section{MATERIAL AND OCCURRENCE}

Specimens of Yakutatia emersoni have not been directly observed in situ, instead all material was collected from the abundant debris available at each of the locations. Comparison of the debris with the actual outcrops indicates, however, that no significant transportation of the material has occurred and the specimens can be regarded as essentially autocthonous. This is not an unusual situation in ichnological studies where erosion and weathering are important prerequisites to the preservation and enhancement of colour or textural contrasts between the trace fossils and their enclosing matrix, particularly in carbonates (Kennedy 1975).

In total, twelve specimens of Y. emersoni have been collected, five of which are figured herein (Fig. 3), and all of which are housed in the Paleontological
Collections of the University of New Brunswick. In contrast to many of the other trace fossils present in the same strata (see below) the ichnospecies is therefore relatively uncommon, as indeed it is in the Cretaceous Kodiak Formation of Alaska (McCann and Pickerill 1986). Although because of the nature of the material very few associated trace fossils have been directly observed, the Grog Brook and Matapedia groups contain the following additional ichnogenera: Asteriacites, Buthotrephis, Chondrites, Cochlichnus, Cosmorhaphe, Glockerichnus, Gordia, Helminthopsis, Neonereites, Nereites, Palaeophycus, Paleodictyon, cf. Petalichnus, Phycosiphon, Planolites, Protopaleodictyon, Scalarituba, Spirodesmos, Spirorhaphe, Stroliborhaphe, Syncoprulus and Taenidium (see Pickerill 1980, 1986; Pickerill and Forbes 1980). The only ichnogenera to have been observed on the same slabs as Yakutatia are poorly preserved examples of Chondrites and Palaeophycus.

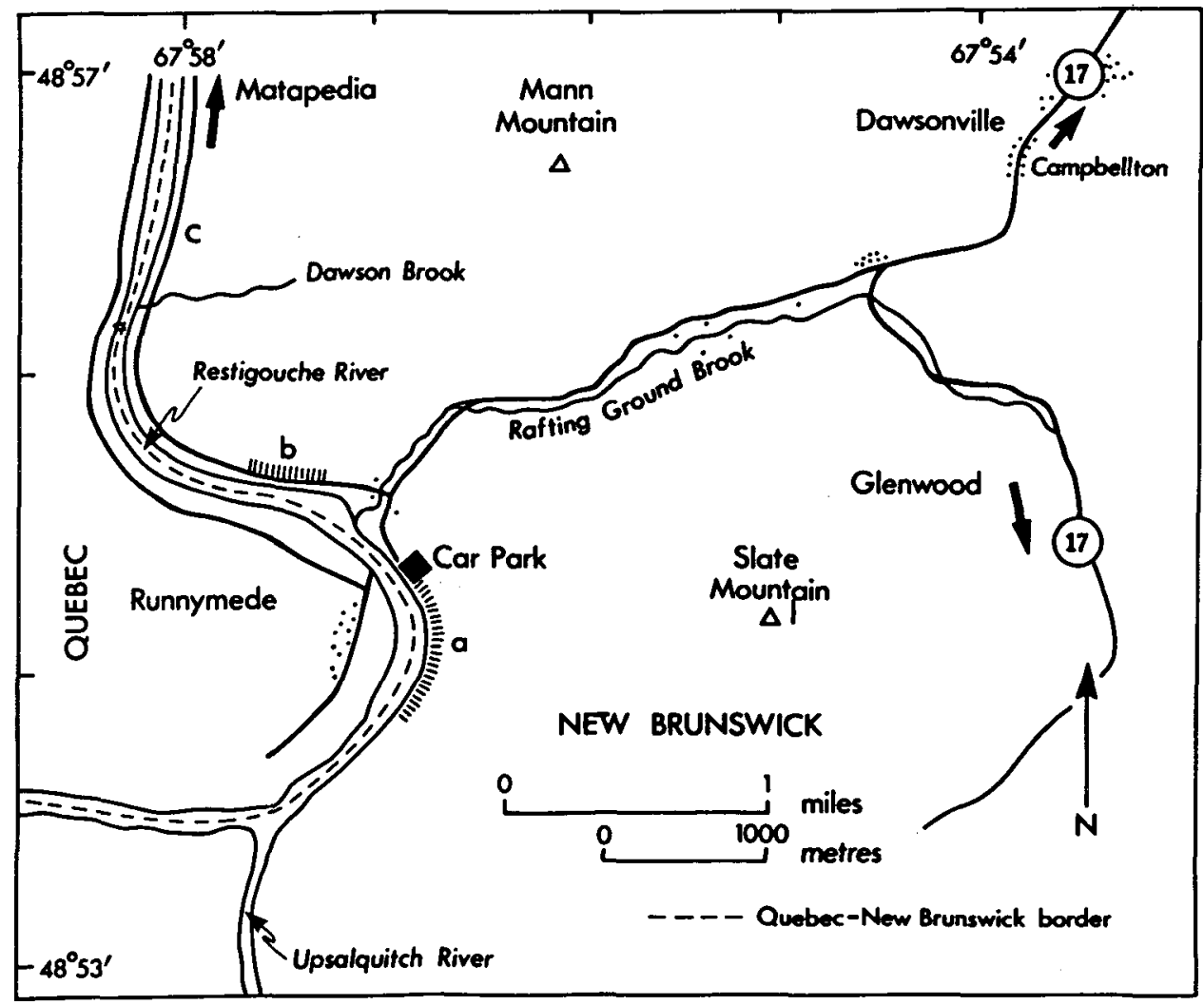

Fig. 2 - Simplified location map (modified after Pickerill 1986) of locations a-c inclusive where Yakutatia as described herein, was collected (see text for details). 


\section{SEDIMENTOLOGY AND DEPOSITIONAL ENVIRONMENT}

The Matapedia Basin has previously been variably interpreted as the site of an ocean (Bird and Dewey 1970), as a blind embayment (McKerrow and Ziegler 1971), and as a remnant of an oceanic basin (Rast and Stringer 1980, Bradley 1983). As correctly pointed out by Nowlan (1983), since there is no conclusive evidence on the nature of the crust underlying the basin all that can really be stated is that it was a relatively deep and narrow linear marine depression. This depression was but one of several which formed in the northeast Appalachians following collisional events associated with the Taconic orogeny (Williams 1977, Rast and Stringer 1980) which occurred in late Early and early Middle Ordovician times. Within this depression the Grog Brook and Matapedia groups accumulated from late Middle Ordovician to Early Silurian times.

The Grog Brook Group, estimated by St Peter (1977) as ca. $7600 \mathrm{~m}$ in thickness, comprises a heterogeneous assemblage of lithotypes. Most typical are interbedded argillaceous sandstones, siltstones and silty argillites, though less commonly polymictic conglomerates, pebbly sandstones and thinly bedded limestones may also be present (St Peter 1977). The majority of trace fossils in the Grog Brook Group, including Y. emersoni, occur in association with $2-40 \mathrm{~cm}$ thick argillaceous sandstones and siltstones interbedded with $1-20 \mathrm{~cm}$ thick argillites. Internally, most sandstones exhibit partial Bouma (1962) sequences with $\mathrm{Tb}-\mathrm{c}, \mathrm{Tb}$, $\mathrm{Ta}-\mathrm{C}$ and $\mathrm{Tc}$, in decreasing order of abundance, being most typical and many of which are spectacularly convoluted. Lower bedding surfaces may be planar and non-erosive or may exhibit morphologically variable flute and groove markings. Many upper bedding surfaces are complexly ripple-marked.

The Matapedia Group is composed of a $1250-4000 \mathrm{~m}$ thick succession of thinly interbedded $(1-5 \mathrm{~cm})$ calcic and ankeritic limestones and calcareous argillites (St Peter 1977). As a result of differential solution of the more limy beds, the rocks have a markedly ribbed appearance such that previous authors (e.g. Ayrthon et al. 1969) have referred to them as "ribbon limestones". The limy beds are generally massive though approximately $10 \%$ exhibit parallel and, or, cross-lamination. Most are planar based and rarely some are erosive. Isolated small-scale channelized lenticular beds may also be present; these are typically infilled with crosslaminated sets. Slumped horizons are locally common. Interbedded calcareous argillites are rarely finely laminated but more typically massive, or where weather ing is pronounced, extremely bioturbated.

To date no detailed and systematic sedimentological studies of either of these groups have been undertaken. Nevertheless, what studies do exist all suggest deposition of both in deep water marine environments. St Peter (1977) suggested both groups to have been deposited by turbidity currents in bathyal or even abyssal environments. Stringer and Pickerill (1980) however, suggested that broadly coeval strata of the Matapedia Group in the Grand Falls area to the southwest (the Carys Mills Formation) were deposited in a deep water slope environment by hemipelagic settling and normal bottomfollowing contour currents with only periodic introduction of material by turbidity currents and other mass flow mechanisms. The present author does agree, however, that the Grog Brook Group represents a succession deposited essentially by turbidity and other mass flow sediment support mechanisms.

Because of the lack of sedimentological studies, it is difficult to realistically assess the precise depositional environments of both groups. Palaeontological studies (Rickards and Riva 1981, Nowlan 1983) suggest that the Matapedia and Grog Brook groups are in part coeval and therefore are merely lateral facies equivalents. Accepting that the Matapedia Group and its lithologically-equivalent correlatives such as the Carys Mill Formation are all in fact slope deposits, it may well be that the Grog Brook Group strata represent mass flow deposits 

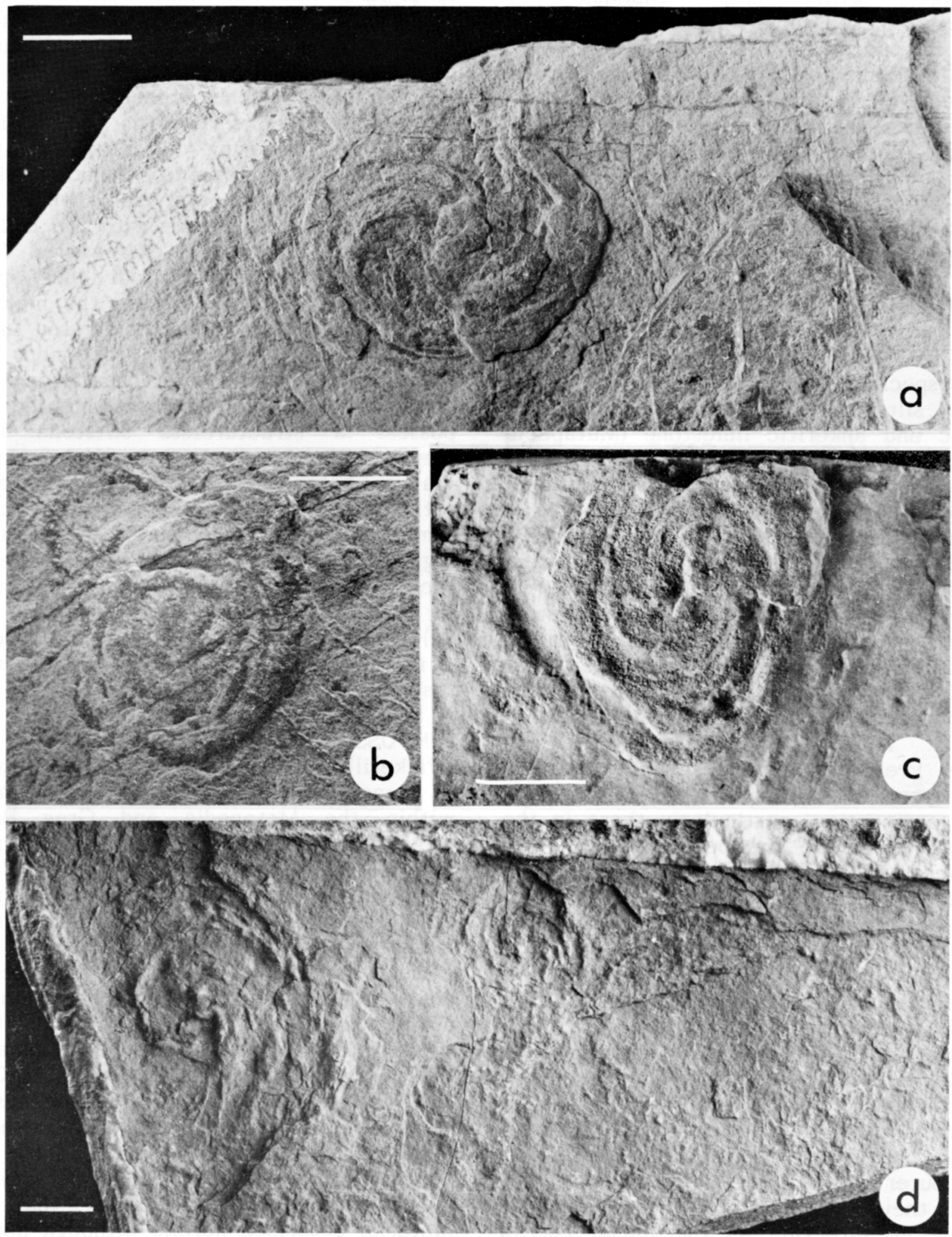

Fig. 3 - Specimens of Yakutatia emersoni from the Grog Brook and Matapedia groups of the Matapedia Basin in northwestern New Brunswick and southwestern Gaspe. a. Specimen preserved in positive hyporelief from the Matapedia Group at Matapedia (locality d). b. Specimen preserved in positive hyporelief from the Matapedia Group at locality c. c. Specimen preserved in positive hyporelief from the Grog Brook Group at locality a. d. Two specimens preserved in negative epirelief from the Matapedia Group at locality b. All specimens found in float material. Bar scale $=1 \mathrm{~cm}$. 
developed within major channels cut through these slope deposits. Although this is speculative, it is notable that Hamilton-Smith $(1971,1980)$ has demonstrated by detailed mapping and lithofacies analysis an analogous scenario in broadly coeval strata in the Matapedia Basin of the Siegas area (Fig. 1) of New Brunswick. It is also notable that the Grog Brook Group consists generally of coarse-grained and thickly bedded mass flow deposits consistent with deposition in channels (e.g. see Walker 1984).

\section{DESCRIPTION}

All specimens are preserved on $1-3 \mathrm{~cm}$ thick siltstone (Grog Brook Group) or calcic and ankeritic limestone (Matapedia Group) bedding surfaces as positive or negative features on soles (respectively, convex hyporelief and concave hyporelief) or negative features on tops (negative epirelief). As all material was collected in float, because of the lack of way up indicators, it proved impossible to determine the exact preservation of all specimens; nevertheless, it is suspected that most are preserved in convex hyporelief, as indeed are examples of Yakutatia from Kodiak Island (McCann and Pickerill 1986). Preservation is generally poor and the specimens have undergone considerable compaction, particularly those in the limestones of the Matapedia Group.

Traces are typically isolate but may occur in close proximity (Fig. 3d). No examples of intersecting specimens were observed. Each specimen consists of a dextrally (Fig. 3a) or sinistrally (Fig. 3c) coiled trace which, as noted by Seilacher (1977) resembles that of the graptolite Cyrtograptus. The coiling is initiated from a single, poorly-preserved curved burrow which then ramifies up to a maximum of four times but more typically three. These secondary ramifications occur on the outer convex side of the initial burrow; they are unbranched and curve in the same direction as the initial burrow thus producing the coiled or spiralled appearance. It is notable that ramification of the burrows on the inner concave sido has not been observed, though this is the more common design in the Kodiak specimens (McCann and Pickerill 1986). The entire spiralled trace forms, at most, a single involution around the acuminate central portion.

Dimensions of the traces are as follows. Diameter of burrows ranges from $1-2 \mathrm{~mm}$ and, bearing in mind the poor preservation, is apparently constant within single specimens apart from where the individual burrows merge with the bedding surfaces at their distal extremities. Total maximum diameter of individual specimens varies from $0.9-3.4 \mathrm{~cm}$, the majority being ca. $2 \mathrm{~cm}$. Minimum diameter varies from $0.5-3 \mathrm{~cm}$; individual specimens are typically ca. $3 \mathrm{~mm}$ shorter than wider.

Burrows are smooth, unornamented and possess a structureless siltstone infill identical in grain size to the enclosing matrix, being differentiated by a colour rather than textural change. The threedimensional form is unknown as sectioning revealed no internal details. Nevertheless, the presence in some specimens of evidence of vertical tiering (e.g. Fig. 3c) suggests that Yakutatia was indeed a truly three-dimensional spiralled burrow system.

\section{DISCUSSION AND CONCLUSIONS}

Pickerill (1980), in his general review of trace fossils and their significance within the Matapedia and Grog Brook groups of the Matapedia Basin, briefly noted a questionable occurrence of Yakutatia within the sequence. At that time only poorly preserved fragmentary material was available, the presently described specimens having been collected since 1980 and their identification as Yakutatia also confirmed by C.K. Chamberlain (personal communication 1981). As díscussed more fully by McCann and Pickerill (1986), the ichnogenus is currently monspecific and is represented by $Y$. emersoni. It is clear from the emended diagnosis of $Y$. emersoni by McCann and Pickerill (1986) that the material described herein, although poorly preserved, conforms in all general features and can therefore be regarded as conspecific.

The recording of $Y$. emersoni from the Matapedia and Grog Brook groups of the 
Matapedia Basin has three important consequences:

1. It represents the first recording of the trace fossil outside of its type location of Kodiak Island. Alaska.

2. It extends the stratigraphic range of the ichnospecies from the Cretaceous (on Kodiak Island) back to the Late Ordovician.

3. It confirms the preferred environment in which the producing organism(s) inhabited as deep water marine. On Kodiak Island, Y. emersoni occurs in thin-beded turbidites interpreted by McCann and Pickerill (1986) to have been deposited in a lobe fringe environment of a deep water submarine fan. In the Matapedia Basin, it occurs in strata believed to have been deposited in deep water slope (Matapedia Group) and channel (Grog Brook Group) environments.

As noted by McCann and Pickerill (1986) several factors remain enigmatic with respect to $Y$. emersoni. First, the three-dimensional structure and the nature of the vertical spiral component is unknown. Second, the nature and affinities of the producing organism are unknown, though as in many other ichnological studies, this is not unusual. Third, the behavioural program producing such a structure is most intriguing. Unfortunately the material described herein adds little to these questions, the answers to which will hopefully be provided once additional recordings of Yakutatia are made from other locations.

\section{ACKNOWLEDGEMENTS}

I am indebted to Jamie Allison for his assistance in the collection of Matapedia Basin trace fossils and Bill Forbes for first drawing my attention to them. I thank C. Kent Chamberlain for examining a selection of the trace fossils and Tommy McCann and Les Fyffe for their constructive reviews of the initial manuscript. Technical assistance during the preparation of the paper was provided by Paul Chenard and Bob McCulloch. The research was undertaken during the tenure of Natural Sciences and Engineering Council Grant A3857 which is gratefully acknowledged.

AYRTON, W.G., BERRY, W.B.N., BOUCOT, J.A., LAJOIE, J., LESPERANCE, P.I., PAVLIDES, L. and SKIDMORE, W.B. 1969. Lower Llandovery of the northern Appalachians and adjacent regions. Geological Society of America Bulletin, 80, pp. 459-484.

BIRD, J.M. and DEWEY, J.F. 1970. Lithosphere plate-continental margin tectonics and the evolution of the Appalachian Orogen. Geological Society of America Bulletin, 81, pp. 1031-1060.

BRADLEY, D.C. 1983. Tectonics of the Acadian orogeny in New England and adjacent Canada. Journal of Geology, 91, pp. 381-400.

FYFFE, L.R., PAJARI, G.E. and CHERRY, M.E. 1981. The Acadian plutonic rocks of New Brunswick. Maritime Sediments and Atlantic Geology, 17, pp. 23-36.

HAMILTON-SMITH, T. 1971. A proximal-distal turbidite sequence and a probable submarine canyon in the Siegas Formation (Early Llandovery) of northwestern New Brunswick. Journal of Sedimentary Petrology, 4l, pp. 752-762.

HAMILTON-SMITH, T. 1980. Stratigraphy and sedimentology of the Siegas Formation (Early Llandovery) of northwestern New Brunswick. In A guidebook to the geology of northeastern Maine and neighboring New Brunswick. Edited by D.C. Roy and R.S. Naylor. 72nd Annual Meeting of the New England Intercollegiate Geological Conference. Boston College Press, pp. 202-21l.

HANTZSCHEL, W. 1962. Trace fossils and Problematica. In Treatise on Invertebrate Paleontology, Part W. Edited by R.C. Moore. Geological Society of America and University of Kansas Press, New York and Lawrence, Kansas, pp. W177-W245.

KENNEDY, W.J. 1975. Trace fossils in carbonate rocks. In The Study of Trace Fossils. Edited by R.W. Frey. Springer-Verlag, New York, pp. 377398.

MCCANN, T. and PICKERILL, R.K. 1986. The trace fossil Yakutatia emersoni from the Cretaceous Kodiak Formation of Alaska. Canadian Journal of Earth Sciences, 23, (in press).

MCKERROW, W.S. and ZIEGLER, A.M. 1971. The Lower Silurian paleogeography of New Brunswick and adjacent areas. Journal of Geology, 7l, pp. 635-646.

NOWLAN, G.S. 1983. Biostratigraphic, paleogeo graphic, and tectonic implications of Late Ordo vician conodonts from the Grog Brook Group, northwestern New Brunswick. Canadian Journal of Earth Sciences, 20, pp. 651-671.

PICKERILL, R.K. 1980. Phanerozoic flysch trace fossil diversity - observations based on an Ordovician flysch inchofauna from the AroostookMatapedia Carbonate Belt of northern New Brunswick. Canadian Journal of Earth Sciences, $17,1259-1270$.

PICKERILL, R.K. 1986. Late Ordovician sedimentary rocks and trace fossils of the Aroostook-Mata- 
pedia Carbonate Belt at Runnymede, Restigouche River, northern New Brunswick. In Centennial Field Guide Project. Edited by D.C. Roy Geological Society of America (in press).

PICKERILL, R.K. and FORBES, W.H. 1980. Ordovician and Devonian sediments, fossils and ichnofossils of northern New Brunswick. In Ordovician, Silurian and Devonian strata of northern New Brunswick and southern Gaspé. Edited by R.K. Pickerill. Canadian Paleontology and Biostratigraphy Seminar, Field Trip Guidebook, pp. 15-29.

NOWLAN, G.S. 1983. Biostratigraphic, paleogeographic, and tectonic implications of Late Ordovician conodonts from the Grog Brook Group, northwestern New Brunswick. Canadian Journal of Earth Sciences, 20, pp. 651-671.

QUENSTEDT, F.A. 1880. Die Rohren-und Steinkorallen. In Petrefactenkunde Deutschlands, 6, Korallen. L.F. Fues, Leipzig, 1093p.

RAST, N. and STRINGER, P. 1980. A geotraverse across a deformed Ordovician ophiolite and its Silurian cover, northern New Brunswick, Canada. Tectonophysics, 69 , pp. 221-245.

RICKARDS, R.B. and RIVA, J. 1981. Glyptograptus? persculptus (Salter), its tectonic deformation, and its stratigraphic significance for the Carys Mills Formation of N.E. Maine, U.S.A. Geological Journal, 16, pp. 219-235.

RODGERS, J. 1970. The tectonics of the Appalachians. Regional Geology Series, Wiley-Interscience, New York, N.Y. 27lp.

SEILACHER, A. 1977. Pattern analysis of Paleodictyon and related trace fossils. In Trace fossils 2. Edited by T.P. Crimes and J.C. Harper.
Geological Journal Special Issue 9, Seel House Press, Liverpool, pp. 289-334.

ST. PETER, C. 1977. Geology of parts of Restigouche, Victoria and Madawaska counties, northwestern New Brunswick. Mineral Resources Branch, Department of Natural Resources, New Brunswick, Report of Investigations 17,69p.

STRINGER, P. and PICKERILL, R.K. 1980. Structure and sedimentology of Siluro-Devonian between Edmunston and Grand Falls, New Brunswick. In A guidebook to the geology of northeastern Maine and neighboring New Brunswick. Edited by D.C. Roy and R.S. Naylor. 72nd Annual Meeting of the New England Intercollegiate Geological Conference, Boston College Press, pp. 262-277.

ULRICH, E.O. 1904. Fossils and age of the Yakutat Formation. Description of collections made chiefly near Kodiak, Alaska. Harriman Alaska Expedition Series, 4, Geology and Paleontology, pp. 125-1246.

WALKER, R.G. 1984. Turbidites and Associated Coarse Clastic Deposits. In Facies Models, second edition. Edited by R.G. Walker. Geoscience Canada Reprint Series 1, pp. 171-188.

WELLS, J.W. 1956. Scleractinia. In Treatise on Invertebrate Paleontology, Part F, Coelenterata. Edited by R.C. Moore. Geological Society of America and University of Kansas Press, pp. F328-F 444.

WILLAIMS, H. 1977. Ophiolitic mélange and its significance in the Fleur de Lys Supergroup, northern Appalachians. Canadian Journal of Earth Sciences, 14, pp. 987-1003.

REVIEWERS: L.R. Fyffe

T. McCann 